\title{
Ectopic Meningioma
}

National Cancer Institute

\section{Source}

National Cancer Institute. Ectopic Meningioma. NCI Thesaurus. Code C5308.

A mening othelial neoplasm that arises from an anatomic site outside the intracranial and intraspinal compartments. 